\title{
PECULIARITIES OF TRAINING FOR CAREER OF LEARNERS WITH MILD INTELLECTUAL DISABILITIES
}

\author{
Rita Virbalienè \\ Šiauliai University, Lithuania \\ Ingrida Baranauskienė \\ Klaipèda University, Lithuania
}

\begin{abstract}
This article describes the peculiarities of training of learners with mild intellectual disabilities. The aim of the article is to highlight problems and different theoretical approaches and theoretically validate the optimal ways of training for career of learners with mild intellectual disabilities. On the basis of scholarly literature, to analyses which areas of training for career are accessible to learners with mild intellectual disabilities. To discuss training for career as a person's readiness to enter adult life from the point of view of education. Young people with mild intellectual disabilities should be supported in understanding own wishes and possibilities. It is important that they start preparing for professional activity in early childhood, since it continues until a person becomes an adult. In the childhood, children should be introduced with different professions and encouraged to take interest in them. They should be encouraged to think about their future work, what they are successful at, as well as about the advantages of different activities.
\end{abstract}

Keywords: career education, special education needs, school.

\section{Introduction}

In the conditions of the processes of globalization, the school cannot stay aside and should adapt to the resulting changes. Education of learners in special needs in general education schools demands the latest knowledge, since education should be accessible to all children irrespective of their abilities and needs. Hence, one of the major characteristics of the system of education is to provide appropriate conditions for children with mild intellectual disorders (MID) to learn according to programmes complying with their individual abilities, as well as applying teaching aids and methods and striving for the optimal quality of learning, which determines MID learners' readiness for career. Training for career is purposeful education of a person's career competences, which aim at helping a learner to develop their career competences essential for successful choice of the field of education so that a learner can successfully choose a profession or 
working activity, as well as at fluent transition from school to adult life, further professional development and lifelong learning. Seeking for successful training for career at school and fluent transition into adult life, it is important that a good transition plan should be prepared which would enable a MID learner, his/her family and teachers to achieve the general aims of the transition process. Upon the implementation of these aims, young people would become economically active citizens having acquired professional training and skills compliant with the expectations and requirements set by adults. Seeking to become mature personalities, young people with mild intellectual disabilities need particular skills - personal independence (disposition / self-determination), problem-solving and setting aims. The development of the feeling of cognising oneself provides young disabled people with a possibility to evaluate individual strengths and challenges, even when seeking for collegial aspirations. The development of the skill to transmit information about own strengths and incurred challenges can be referred to as personal independency and self-determinance. It can be concluded that "independent (self-determinant) individuals can control own life to some extent, since they can determine the future goals related to their reality and situation being aware of own strengths and needs" E. M. Ankeny, J. P. Lehmann, (2011).

The skills of personal independence (self-determinance) provide young people with possibilities to assume adult roles E. M. Ankeny, J. P. Lehmann, (2010); S. S. Field, M. D. Sarver, S. F. Sha (2003). However, training of persons in special needs for career is still one of the areas of concern in the Lithuanian system of education.

Why is it important to allot sufficient attention to the development of the competences for training for career for learners with mild intellectual disabilities in school age?

Why does transition from school to working activity frequently become a challenge and a problem for youth in special education needs?

The object of the article - peculiarities of training of learners with mild intellectual disabilities.

The aim of the article is to highlight problems and different theoretical approaches and theoretically validate the optimal ways of training for career of learners with mild intellectual disabilities.

Objectives of the article:

- $\quad$ On the basis of scholarly literature, to analyse which areas of training for career are accessible to learners with mild intellectual disabilities.

- To discuss training for career as a person's readiness to enter adult life from the point of view of education.

Seeking to reveal the peculiarities of training for career of learners with mild intellectual disabilities in the process of the transition from school to adult life, 
the aspects of training for career and entering adult life are explored in further parts of the article.

The research method applied in the article is critical review M. J Grant, A. Booth (2009) and analysis of scholarly literature.

\section{Methodology}

The methodological fundamental of the research is existential and humanist philosophy. According to the representatives of existential philosophy A. Mickūnas, D. Stewart, (1994); Rudestam, (1982); W. Furman, (2001), every human being is unique and valued - every human being has an individual world outlook and no person experiences the world in the same way as others. Organising the process of training for career of young people with mild intellectual disabilities, it is important to observe the idea of existential philosophy: a person's actualisation "now and here" is most significant; the only situation that we can experience as human beings is the present - we can remember the past and we can plan the future. Therefore, the present situation is the only one that can be changed when planning youth career. The work is based on the pedagogical conception of existentialism that encourages the educator and the learner to take interest in essential issues of human existence, and to overcome satisfaction with life grounded on material well-being B. Bitinas, (2006). From the existentialists' viewpoint, a person (including a child) is free to make choices, whereas the duty of an educator is to consider a child's world outlook and teach $\mathrm{him} /$ her to make conscious choices, to help his/her understand and regard own possibilities.

Humanist philosophy is related to respect for human right to freedom, equality, development of inborn abilities and features, as well as personality development. Its main principle is recognition of every person's value and respect. According to Rogers (1973), if a young person "is willing to learn and develop, strives for knowledge and good accomplishment of everything, and feels desire to create", the pre-professional education that is inseparable from the formulation of personal education goals in the content of training for career is properly organised. The school, primarily, should help every learner to cognise oneself, to perceive own identity and search for purport of life. Hence, education should be directed towards a person, his/her self-expression and development. It is assumed that everything can be achieved by satisfying the essential needs of a child: she/he should be respected, loved, psychologically safe and valued by others, as well as able to value him/herself, plan and create own future. 
Rita Virbaliene, Ingrida Baranauskiene. Peculiarities of Training for Career of Learners with Mild Intellectual Disabilities

\section{Training for career and choice of a profession}

The rapid processes of globalisation, demographic changes, economic fluctuation as development of technologies shock, transform and change the world and way of human life. Integration into the labour market in the rapidly changing environment is not an easy task for any young person, whereas it is much more complicated for a young person with mild intellectual disability. One of the conditions for successful transition of persons in special education needs from school to working activity is purposeful planning of learners' career. Preparation of an individual plan for transition would help a young person, his/her family and teachers to achieve general aims of the process of transition. Upon the implementation of these aims, young people would become economically active citizens having acquired professional training and skills compliant with the expectations and requirements set for adults.

Education for career is a purposeful development of a person's career competences. Its main aim is to help a learner to develop their career competences essential for successful choice of the field of education so that a learner can successfully choose a profession or working activity, as well as at fluent transition from school to adult life, further professional development and lifelong learning. The problem of the choice of a profession has been explored since old times from various aspects. In his book "The Republic", Plato discussed the inborn differences of people determining the nature of their professional activity.

Nowadays, different theories are employed to discuss the issues related to the choice of a profession: development and self-perception by D. E. Super (1961, 1962), typology by J. Holland (1973), social learning theory by J. Krumboltz (1979, 1990), professional aspirations L. Gottfredson, (1981), as well as adaptation to work by R. Dawis $(1984,1992)$.

The afore-said theories help to understand the processes of the choice of a profession, decision-making, and rendering support in case of difficulties. Today, these theories are combined in a unified theory of convergence, though their diversity is stated L. Jovaiša, (1999). Almost a hundred of years ago, F. Parson, the founder of professional orientation, formulated three main principles of the successful choice of a profession: good cognition of the self, awareness of the world of professions, and combination of this knowledge (Parson, 1909). Training for career and the implementation of pre-professional education is organised differently in different countries. It largely depends on the system of education, culture, customs and traditions of every country. In some countries, preprofessional education is implemented as an individual part of the system of education that has its own programme, duration and implementing institution. In other countries, pre-professional education is implemented integrating the content 
of education for career into general education and vocational training considering the peculiarities of understanding and experience conditioned by learners' age.

Only a small group of Lithuanian researchers have analysed working, preprofessional and professional training of disabled persons: A. Juodraitis (1999, 2001) disclosed the theoretical fundamentals, D. Alifanoviene (2001) analysed the significance of social and household abilities, L. Kaukenaite (2001) explored the state of vocational education, J. Ruškus $(2000,2001,2002,2004)$ highlighted the significance of teachers' provisions, I. Baranauskienè (2003, 2004, 2008) investigated the connections between the vocational training of young people with mild intellectual disabilities and their professional adaptation, A. Galkiené, V. Gevorgianienè (2008) analysed entrepreneurship education of disabled learners, and G. Dulnevas (1969), referring to the research and experience of other countries, explored the necessity of changing the system of vocational education in special schools. He believed that the earlier children started education in special schools, the longer the period of education would be. This was conditioned by children's insufficient intellectual, social and physical maturity to choose a profession and start intependent life. The scientific research of V. Karvelis (1969, $1979,1981,1987,1994,2001)$ had a great impact on the theory and practice of the vocational training of disabled people in Lithuania. The latest research into the vocational training of the disabled, their adaptation in the labour market and professional rehabilitation has been conducted by I. Baranauskienè (2000, 2002a, 2002b, 2003a, 2003b), I. Baranauskienè, J. Ruškus (2004), I. Baranauskienè, A. Juodraitis (2008) and others.

Implementing training for career in general education schools in Lithuania, it is highly important to help learners to choose the profile of learning, a profession and working activity. Professional consultation should continue in vocational training institutions constantly checking and evaluating the righteousness of learners' choice of a profession. Consistently working with learners with mild intellectual disabilities in educational institutions, purposefully applying the attained aims and defining clear connections between the social environment and experience of learners with mild intellectual disabilities, as well as choosing appropriate methods, these learners are exposed to all possibilities to learn with others and feel full-fledged members of the community. Most researchers claim that a person should start preparing for the integration into the labour market in early childhood, and it may last a long time or even the whole life. In the childhood, a child should be introduced with different professions and encouraged to take interest in them. They should be encouraged to think about their future work, what they are successful at, as well as about the advantages of different activities.

The Description of the Procedure of the Implementation of Professional Orientation was confirmed following the Order of the Minister of Education and 
Rita Virbaliene, Ingrida Baranauskiene. Peculiarities of Training for Career of Learners with Mild Intellectual Disabilities

Science and the Minister of Social Security and Labour "On the Approval of the Description of the Procedure of the Implementation of Professional Orientation" (No. V-1090/A1-314 of 4 July 2012) implementing Part 2 of Article 18 and Part 3 of Article 26 of the Law on Education of the republic of Education and Article 8 of The Law on Vocational Training of the Republic of Lithuania. It is stated that "The aim of professional orientation is to help persons to purposefully choose possibilities appropriate for their education and employment, to provide conditions to acquire career competences, to actively create own career (i.e. a sequence of lifelong, self-expression and working experiences significant for a person and the society). Professional orientation is implemented by providing services regarding training for career, professional information and professional consultations."

The Description highlights that the services of professional orientation are provided to all persons, as well as the importance of assuring equal opportunities and assessment of needs. Observing the principles of impartiality and free choice, the implementers of professional orientation should deliver support to a person in choosing and realising the best possibilities of his/her career. To attain the aforesaid aim, educators apply different forms of professional information: training for career is integrated inito subject lessons and after-class activities, such as subjectspecific, technical, arts and sports circles, school events, such as excursions, meetings with representatives of different professions, exhibitions, thematic evenings, lectures and conferences; meetings with the class teacher; as well as communication with parents. Seeking to achieve good results in the process of professional information, educators apply different methods: observation, verbal (conversations and stories), mass media, such as films, TV programmes, posters, special literature, dictionaries, reference books, booklets, brochures, etc.

In Lithuania, pre-professional education is implemented through integrating the content of training for career into general education and vocational training. In the teacher's book "Education for Career" it is stated that "seeking to find a place in the modern world of labour, a person should be able to purposefully act in the changing situation and life $<\ldots>$ considering the labour demands and aims of personal self-realisation. She/he needs career competences defined as the aggregate of attitudes, knowledge, understanding and abilities based on the cognition of oneself and own career, its planning, management and combination with other aspects of life". Four areas of career competences are distinguished in the integrated education for career outlined in general education programmes: self cognition, career possibilities, career planning and career implementation.

Four levels pf competence development are defined:

- $\quad$ The first level - acquisition of primary knowledge, understanding and abilities, formation of attitudes; 
- $\quad$ the second level - acquisition of main knowledge, understanding and abilities, formation of attitudes;

- $\quad$ The third level - acquisition of specific knowledge, understanding and abilities, formation of attitudes;

- $\quad$ The fourth level - development and improvement of the acquired knowledge, understanding and abilities, consolidation of attitudes.

The general education plans and general vocational training plans of Basic and Secondary Education General Programmes of Lithuania outline that schools should implement learners' education for career, yet at the same time, education institutions are given autonomy and freedom to organise orientation (career) services. However, on 30 September 2011, following Article 2.4 of Order No. V1795 "On the Approval of the Description of the Procedure of Organising Education of Learners in Special Education Needs the Minister of Education and Science confirmed that "since 1 September 2012 learners that have accomplished individualised programmes of basic education can continue learning in accordance with the programme of vocational training or learn according to the programme of social skills development". It can be concluded that the provisions of the order of the Minister of Education and Science is of discriminating character in terms of disabled children (with intellectual disabilities) and depriving them of employing the career competences defined in the "Model" of level four.

The order of the Minister of Education and Science deprives learners in special education needs of learning according to adapted or individualised secondary education programmes and directs them to continue studies only according to vocational training programmes or learn according to the programme of social skills development. This order is directly applied to all children with intellectual disabilities leaving no possibilities to continue learning after individual evaluation, as children with some disabilities, such as autism, or having mild intellectual disorders, can successfully integrate into general education schools and learn according to adapted programmes of primary and basic education. They are deprived of the possibility to continue studies and are forced to choose a vocational or special school, where they are educated with learners having major intellectual disabilities. Upon the completion of 10 grades, learners have the only possibility to study in schools of technologies and business, agriculture, handicrafts and food industry, and vocational training centres.

According to J. Ruškus (2004), persons in special needs are educated in two ways: they are either integrated into general education groups, or education is organised in special groups. Upon the successful completion of school, persons acquire a certificate of a qualified worker, whereas the ones who complete secondary education programme alongside with vocational training get a diploma. 
Rita Virbaliene, Ingrida Baranauskiene. Peculiarities of Training for Career of Learners with Mild Intellectual Disabilities

In specialised vocational schools, persons in special needs develop skills of independent life alongside with the main aim - training for career, and the state takes care of its partial maintenance.

Training for career learners in special education needs remains one of the problem areas of the Lithuanian system of education. Referring to and applying the experience of other countries in the practice of Lithuanian education could improve readiness of learners for life and possibilities of acquiring professional skills. Transition from school to adult life frequently poses challenges for young persons in special education needs.

According to R. Laužackas, E. Danilavičius, O. Guskienė (2004). high requirements are set for vocational training in our society: it should provide with professional and general education knowledge compliant with the level of modern science and technologies, general cultural values, as well as professional competences in the selected field. Vocational training should also provide conditions essential for the development and renewal of the acquired knowledge enabling a worker to adapt to the constantly changing conditions on the labour market.

Having completed an exhaustive analysis of scholarly literature, I. Baranauskienè, J. Ruškus (2004) distinguish four models of vocational training of the disabled: socio-professional inclusion (liberal market), professional competitiveness or dual, professional segregation (from work simulation to narrow specialisation), and vocational training model.

Every model of the vocational training of the disabled has its advantages and disadvantages, yet neither of them guarantees the success in professional integration of learners with mild intellectual disabilities. One of the conditions of successful transition of learners in special education needs from school to working activity is purposeful planning of their career. Preparation of an individual plan of transition would help a learner, his/her family and teachers to achieve the general aims of the transition process. Upon the implementation of these aims, young people would become economically active citizens having acquired professional training and skills compliant with the expectations and requirements set by adults.

Lithuanian researchers have conducted research in the readiness of learners with mild intellectual disabilities to enter adult life, professional opportunities and choice and claim that a frequent obstacle preventing MID learners from employment is the lack of communication skills, irresponsibility, insufficient psychological and physical readiness, lack of literacy and mathematical sills, appearance and influence of other people I. Baranauskienė, J. Ruškus, (2004). These learners are often unable to assess own possibilities and situation on the labour market, which frequently leads to disappointment with own professional abilities, insufficient readiness to work, unfavourable attitude of employers, and 
emotional difficulties when integrating into the labour market. Insufficient thinking abilities of these learners frequently become reasons of employers' disappointment, underestimation of a worker and doubts; employers tend to choose other employees rather than those with MID I. Baranauskiené, A. Juodraitis, (2008). MID persons painfully put up with colleagues' negligence; they are often made to do worse paid jobs, and therefore, they frequently balance on the verge of poverty. Young people with MID have difficulties to apply to working conditions, and their career is often accompanied with alcohol consumption, dissatisfaction with own profession, work and salary. MID persons often experience social exclusion due to the inability to perform the roles imposed by the society, whereas social benefits become the main source of income I. Baranauskienè, J. Ruškus, (2004).

Career is lifelong learning, cognition of oneself, self-expression and working experience. Due to the changes in the society, culture, economy and technologies, the conception of career has changed from the conception that the state is responsible for career, nowadays a person his/herself is responsible for own career and its management. Therefore, it is important that modern school educates a responsible person seeking for career, which is quite difficult for a person with mild intellectual disability.

\section{Conclusions}

Young people with mild intellectual disabilities should be supported in understanding own wishes and possibilities. It is important that they start preparing for professional activity in early childhood, since it continues until a person becomes an adult. In the childhood, children should be introduced with different professions and encouraged to take interest in them. They should be encouraged to think about their future work, what they are successful at, as well as about the advantages of different activities.

One of the conditions of the transition of learners in special education needs from school to working activity is purposeful planning of learners' career. A good transition plan would enable a MID learner, his/her family and teachers to achieve the general aims of the transition process. Upon the implementation of these aims, young people would become economically active citizens having acquired professional training and skills compliant with the expectations and requirements set for adults. Close cooperation between parents and teachers helps to create favourable conditions for the social maturity of the disabled.

In scholarly literature, training for career is considered as a continuous process of educating learners with mild intellectual disabilities in which they acquire and develop their competences. Referring to the theoretical analysis, it is possible to claim that the main obstacle of the integration of the disabled into the 
Rita Virbaliene, Ingrida Baranauskiene. Peculiarities of Training for Career of Learners with Mild Intellectual Disabilities

labour market and their professional adaptation are: negative attitude of the society and employers towards disability, lack of motivation and initiative of the disabled, lack of willingness to work, and unfair evaluation of own situation. A systemic programme of vocational training is essential for the integration of the disabled.

\section{References}

Alifanovienè (Vitkauskaitė), D. (2001). Teoriniai socialinio darbo modeliai, Šiauliai: ŠU, 9-10. Ankey, E. M., \& Lemann, J. P. (2010). He transition lynchpin: The voices of individuals with disabilities who attended a community college transition program. Comunity College Journal of Research and Practice 34, 477-496.

Ankey, E. M., \& Lemann, J. P. (2011). Journey towards selfdetermination: Voices of students with disabilities who participated ina secondary transition program on a community college campus. Remedial and Special Education, 32 (4). 279-289.

Baranauskienè, I. (2001). Neigalaus jaunimo profesines perspektyvos kvalifikuotoje Europoje. Darbinis ir profesinis neigaliuju rengimas: turinio kaita. Šiauliai: Šiaurès Lietuvos leidykla.

Baranauskienè, I. (2008). Neigaliuju dalyvavimas darbo rinkoje: socioedukaciniai aspektai:habilitacijos procedūrai teikiamu mokslo darbu apžvalga: Prieiga internete: $<$ http://www.vpu.lt/vpu_internet/m/m_files/wfiles/file6428.pdf $>$.

Baranauskienè, I., \& Gudinavičius, B. (2008). Tarpininkavimas profesinès reabilitacijos procese: tarpininkavimas neigaliojo asmens profesinès adaptacijos procese. Šiauliai: Šiaulių universiteto leidykla.

Baranauskienè, I., Valčiukienè, L., \& Vinikaitytė, J. (2008). Integruotai ugdomų neigaliujų profesinio Rengimo ir papildomo ugdymo sąveikos aspektai. Specialusis ugdymas. Nr. 1 (18). 148-157.

Baranauskienè, I. (2013). Innovative study methods in the second cycle study programme of social work. Innovative study methods in the second cycle study programme of social work. Methodical guide book for teachers. JSC „BMK Leidykla“. Vilnius.

Baranauskienè, I. (2007). Nežymiai sutrikusio intelekto asmenų, baigusių profesinio rengimo îstaigas, profesinès adaptacijos ypatumai. Pedagogika (88): 57-62.

Baranauskienè, I., \& Juodraitis, A. (2008). Neįgaliujų profesinè reabilitacija: sėkmės prielaidos. Šiauliai: VŠI Šiauliu universiteto leidykla.

Baranauskienè, I., \& Ruškus, J. (2004). Neigaliuju dalyvavimas darbo rinkoje: Profesinio rengimo ir profesinès adaptacijos sąveika: Monografija, VšI Š Šiaulių Universiteto leidykla.

Baranauskienè, I., Elijošius, E., \& Karvelis, V. (1997). Jaunuolių, turinčių psichofizinio vystymosi sutrikimų, profesinis ir socialinis rengimas. Vilnius: Leidybos centras.

Barkauskaite, M. (2007). Profesinis konsultavimas ir orientavimas šiuolaikinio profesinio rengimo kontekste. Acta pedagogika Vilnensia., 18: 106-120.

Bendrojo ugdymo mokyklu ir profesinio mokymo istaigu mokiniu ugdymo karjerai modelis http://www2435.vu.lt/wpcontent/dokumentai/Ugdymas_karjerai/uk_modelis_\%283\%29 .pdf

Bitinas, B. (2006). Edukologinis tyrimas: Sistema ir procesas. Vilnius: Kronta. 
Dawis, R. V., \& Lofquist, L. H. (1984). A psychological theory of work adjustment: An individual-differences model and its applications. University of Minnesota Press.

Dawis, R. (1992). The individual differences tradition in counseling psychology. Journal of counseling psychology, 39 (1), 7-19.

Dèl Profesinio orientavimo vykdymo tvarkos aprašo patvirtinimo http://www3.1rs.1t/pls/inter3/dokpaieska.showdoc_1?p_id=430003\&p_query=\&p_tr2=2

Field, S. S., Sarver, M. D., \& Shaw, S. F. (2003). Self- determination: Akey to success in postsecondary education for students with learning disabilities. Remedial and Special Education, 24, 339-349.

Juodraitis, A. (1999). Asmenybès psichologinès adaptacijos prielaidos. Šiauliai.

Juodraitis, A. (2001). Asmenybès elgesio transformacijos: delikvencija ir prevencijos galimybès. Realising educational problems. ATEE Spring University, Klaipèda.

Jovaiša, L. (1999). Profesinio konsultavimo psichologija. Agora. Vilnius.

Furman, W. (2001). Working models of frendships. Journal of Social and Personal Relationships, 18, 583-602.

Gevorgianienè, V., Galkienė, A., \& Grincevičienė, V. (2008). Verslumo gebėjimų raiška kryptingo ugdymo sąlygomis. Pedagogika, 89, 90-98.

Gottfredson, L. S. (1981). Circumsciption and compromise: A developmental theory of occupational aspirations [Monograph]. Journal of Counseling Psychology, 28, 545-579.

Grant, M. J., \& Booth, A. (2009). A typology of reviews: an analysis of 14 review types and associated methodologies. Salford Centre for Nursing, Midwifery and Collaborative Research (SCNMCR), University of Salford, Salford, UK, †School of Health and Related Research (ScHARR), University of Sheffield, Sheffield, UK/ The authors /Journal compilation (C) 2009 Health Libraries Group. Health Information and Libraries Journal, $26,91-108$

Holland, J. L. (1973). Making Vocational Choices. Theory of Careers. Englewood Cliffs, NJ: Prentice-Hall.

Karvelis, V. (1979). Anomalus vaikas - šeima - mokykla. Kaunas: Šviesa.

Kaukènaitè, L. (2001). Darbinio mokymo būklè specialiojoje (sutrikusio intelekto vaikams) mokykloje. Specialusis ugdymas, I (IV), 40-51.

LR Švietimo ir mokslo ministro isakymas „, Dèl bendrojo lavinimo ugdymo turinio formavimo, vertinimo, atnaujinimo ir diegimo strategijos patvirtinimo" $2007 \mathrm{~m}$. gegužès $23 \mathrm{~d}$. Nr . ISAK-970, http://www.upc.smm.lt/ekspertavimas/biblioteka/failai/UT_strategija_200705-23.pdf

Mickūnas, A., \& Stewarts, D. (1974). Exploring Phenomenology: A guide to the field and its literature.American Library Associationleidyklos. 1990. Ohio University Press.

Parsons, F. (1909). Choosing a vocation. Houghton Mifflin.

Rogers, D. P. (1973). Systens analysis of correlates of network openness in organition communication. Unpublished Doctoral Disertation. Ohio University.

Ruškus, J. (1999). Sisteminè analize: koncepcijos raida ir esminiai principai. Socialiniai tyrimai: tarpdisciplininis požiūris. Šiauliai: Šiaulių universitetas. p. 104.

Ruškus, J. (1999). Negalè kaip socialinis-kultūrinis konstruktas: nuo statų problema. Socialiniai mokslai, 3 (20), 58-66.

Ruškus, J. (2000). Specialiojo pedagogo socialinių nuostatų, pedagoginès sąveikos ir mokyklinès socializacijos ryšys. Socialiniu mokslu (edukologijos) daktaro disertacija.

Ruškus, J. (2002). Negalès fenomenas: monografija. Šiauliụ Universiteto Leidykla.

Super, D. E., Tiedeman, D. V., \& Borow, H. (1961). "Vocational Development." The Personnel and Guidance Journal 40.1 / 11-15. 
Rita Virbaliene, Ingrida Baranauskiene. Peculiarities of Training for Career of Learners with Mild Intellectual Disabilities

Laužackas, R., Danilevičius, E., \& Gurskienė,O. (2004). Profesinio rengimo reforma Lietuvoje. Parametrai ir rezultai. Vytauto Didžiojo universiteto leidykla.

Sowers, J., \& Powers, L. (1995). Enhancing the participation and independence of students with severe psysical and multiple disabilities in performing community activities. Mental retardation. 33p.

Švietimo ir mokslo ir Socialinès apsaugos ir darbo ministrai ísakymu „Dèl profesinio orientavimo vykdymo tvarkos aprašo patvirtinimo“ (2012 m. liepos 4 d. Nr. V-1090/A1314) igyvendinant „,Lietuvos Respublikos švietimo ịstatymo (Žin., 1991, Nr. 23-593; 2011, Nr. 38-1804) 18 straipsnio 2 dali, 26 straipsnio 3 dali ir Lietuvos Respublikos profesinio mokymo istatymo (Žin., 1997, Nr. 98-2478; 2007, Nr. 43-1627) 8 straipsni. https://www.etar.lt/portal/lt/legalAct/TAR.F0E90ABE387D 